\title{
KAYA TURAN
}

The Peasant, The Pagan, and The Christian: Landscape and Cinematic Spectatorship in Michelangelo Frammartino's Le Quattro Volte 


\section{KAYA TURAN The Peasant, The Pagan, and The Christian: Landscape and Cinematic Spectatorship in Michelangelo Frammartino's Le Quattro Volte}

With his 2011 film Le Quattro Volte (The Four Times), filmmaker and video installation artist Michelangelo Frammartino introduces the spectator to another kind of world. Shot in the mountainous rural region of Calabria in southern Italy, the film takes up Pythagoras' proposition that "we must know ourselves four times": as human, animal, vegetable, and mineral. ${ }^{2}$ Sequentially illustrating the modes of being of a goatherd, goat, tree, and charcoal, Le Quattro Volte suggests an alternative to the Anthropocene in which everything around is alive with autonomy and unity. Frammartino attributes many of the qualities of the film to the region of Calabria itself. The ancestral home of both Frammartino and Pythagoras, Frammartino claims that "this land has taught me to put man's role in perspective and turn my gaze away from him.." Le Quattro Volte does not simply present this world for the viewer to passively absorb; rather, it invites the viewer in, to engage and experiment with its spatialities, temporalities, and ontological truths. In his essay Uncanny Landscape, philosopher Jean-Luc Nancy presents a framework of landscape engagement through which we might better understand Le Quattro Volte and its imperatives. Nancy contrasts peasant and pagan engagement with the land, in which the land is understood and co-existed with in accordance with its omni-presence, with the Christian relation to landscape in which presence is withdrawn, replaced by absence and distance. I argue that in Le Quattro Volte, Michelangelo Frammartino, with the aid of the viewer, develops a set of representational strategies that signify cinematic "presence," suggesting a "pagan" mode of spectatorship in which all things (animal, vegetable, and mineral) are revealed as having autonomy, perspective, temporality, and unity. Furthermore, I contend that this "alternative" reality is not self-enclosed, as the film world opens onto the spectatorial world. Using non-anthropocentric framing, rhythm, off-screen space, and engaged spectatorship, Le Quattro Volte ascribes cinematic presence to the region of Calabria as a whole, encouraging viewers to try out new modes of spectatorship and being in which existential hierarchies are abolished. 
With Le Quattro Volte, Michelangelo Frammartino set out to answer the question: "Can cinema free itself of the dogma which dictates that human beings should occupy the leading role?"4 The film thus starts with a human protagonist (a goatherd), and sequentially passes on to more and more (seemingly) alien protagonists (a goat, tree, and charcoal, respectively). In reality, the subject of the film is not four distinct protagonists but "one protagonist in four forms,"5 as the film represents a process of the transmigration of a soul as each of its "bodies" passes away. Following this pattern, Frammartino uses a minimalist and quasi-documentary film style without overt visual or sonic drama to create a "horizontal aesthetic" in which agency is equitably distributed. The film thus plays on concepts of cinematic foreground and background, allowing traditional background elements to come to the fore, and vice versa. Because of its minimalist and (relatively) non-imposing form, Frammartino asks that the viewer "complete" the film, taking on an active role to realize its non-anthropocentric aims.

Though Calabria's population is largely Roman Catholic at present, it has held on to its pagan and animist religious roots, integrating many traditional practices and beliefs into its Christian faith. This is seen in Le Quattro Volte, as Christian practices such as a re-creation of the crucifixion co-exist with pagan rituals. Often central to animist belief is the idea that "all things are full of gods," a sense that I contend is evident in Le Quattro Volte's formal and thematic insistence on a plurality of perspectives. Calabria thus appears as "a land which straddles the confines between present and past, between modern and ancient beliefs, between village and countryside."8

Accordingly, Calabria and Le Quattro Volte serve as interesting sites with which to consider Jean-Luc Nancy's conception of land and landscape as presented in his essay Uncanny Landscape. Nancy offers three forms of engagement with land: peasant, pagan, and Christian. Nancy's categorizations are not necessarily literal, as they have more to do with one's conceptual and practical relation to the land than actual occupation or religious practice. The peasant, for Nancy, is "someone whose occupation is the country and the land," who works in, on, and with the land. The peasant actively takes up the land and lives among it, inside of it - it is an "order of the body, of embodied extension disposed and exposed: the earth such that it is nothing other than itself." 10 The peasant is always also the pagan: "the one who knows and worships the gods of the country, the gods who are present in each corner of the field." "11 For the pagan (and the animist), divinity is found in and among the earth, distributed amongst all things and beings. It is a religion of presence: "the pagan lives in the continuous presence of the gods, or he is someone for whom the gods are presence itself; someone for whom the divine is distributed among numerous gods because it is the divine of presence." 12 The complementary modes of peasant and pagan are contrasted with the Christian relation to landscape. In opposition to the pagan, the Christian's land is defined by absence, by a divinity which has withdrawn from the land and is located elsewhere, beyond. It is in the Christian mode of thought that "landscape" (as opposed to land) comes into play - Nancy traces the etymology of the word to identify its original meaning as a "corner" of the land, requiring a withdrawn spectator that takes it up at a distance, in perspective. Le Quattro Volte, with its non-anthropocentric project and animist influence, seeks to make the viewer into a "pagan" spectator by cinematically emphasizing the "presence" of all things and modes of being.

Beyond the content of the film, in which "landscape, weather, non-human animals, vegetation, dust, charcoal, and smoke are all given due screen-time"13 and even take on "leading" roles (the movement of background to foreground), the film's form affords cinematic "presence" to non-human animals and objects. Cinematic presence is understood here as a set of representational strategies that insist on the agency, autonomy, and aliveness of animals and objects, realized in Le Quattro Volte as a "new materialist political project" which seeks to "recognize distributive agency across ontological categories." 14 The most evident case of this may be Frammartino's usage of point of view (POV) shots for non-human beings. 
As the film moves from human-centered to non-human, the viewer is at times asked to identify with the gaze of a goat, or of a tree. In one such instance, the camera looks out at the world from the perspective of a chopped down tree, as it "looks" out at the world from the back of a truck (fig. 1). Though a tree of course does not "look," at least in a human sense, the use of POV shots nonetheless suggests some agency and even identity. Inherent here is a critique of film language itself and its anthropocentric assumptions, with terms like "POV" or "close-up" typically referring specifically to the framing of human beings. Especially in the section focusing on the goat, the film also alters its use of camera height, taking on a lower height to accommodate the form of the goat. This serves not only to emphasize the significance of the goat, but also to move human beings into the cinematic background, as a lower camera height often fragments and cuts off the human form (fig. 2). The secret presence that is revealed is not limited to the film's various "protagonists," as the film suggests the agency and unity of all things. The mis-en-scene frequently focuses on the microscopic and its pervasiveness, from dust to ants. In a telling shot, the smoke from burning charcoal spreads across the forest, enveloping, and sinking into the landscape in its entirety (fig. 3). In its pagan and animist tendencies, Le Quattro Volte emphasizes not only the spiritual autonomy of all things but also their unity and oneness.

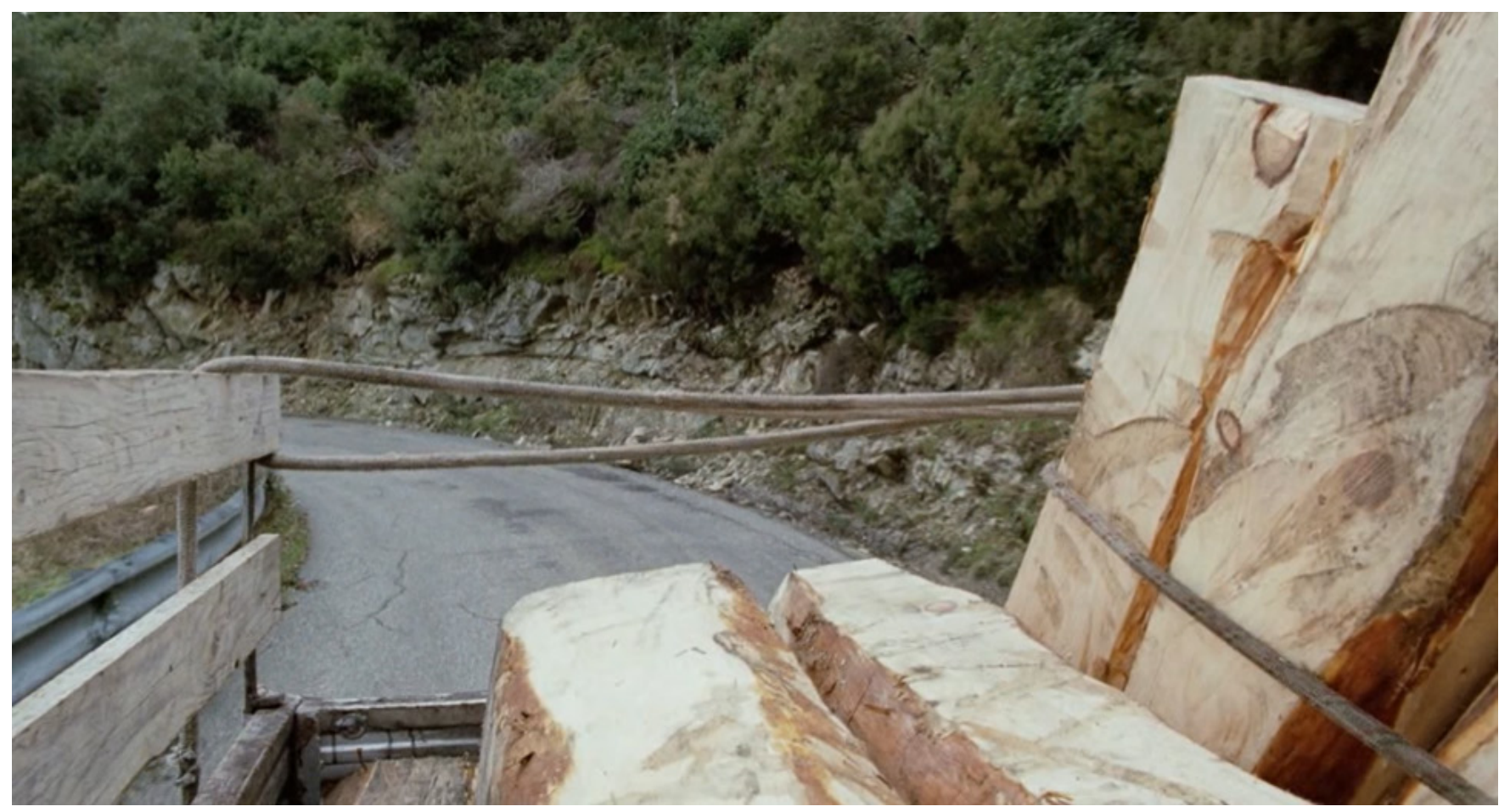

Figure 1. Le Quattro Volte, directed by Michelangelo Frammartino (2010; Italy: New Wave Films, 2011), DVD. 


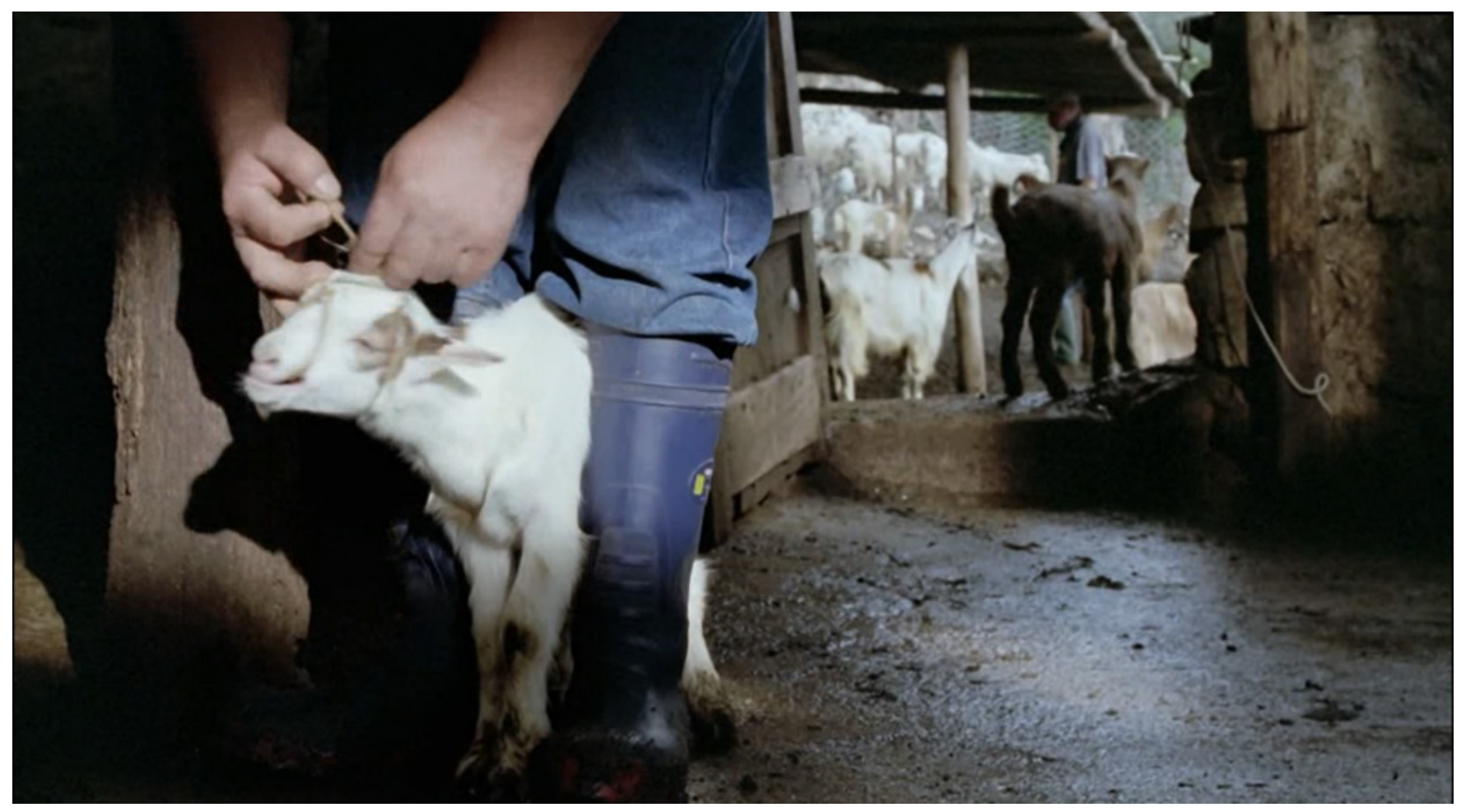

Figure 2. Michelangelo Frammartino, Le Quattro Volte, 2010.

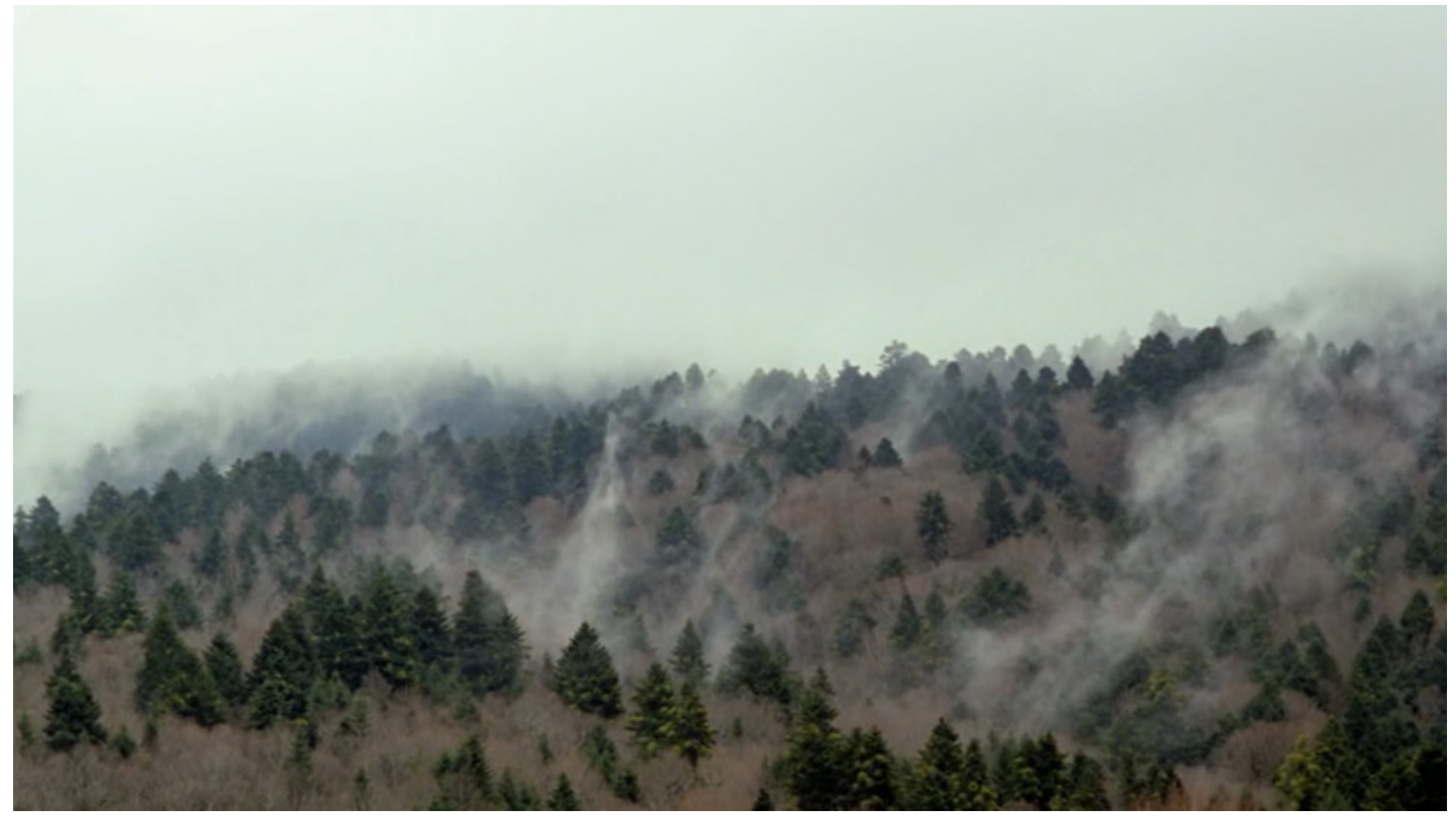

Figure 3. Michelangelo Frammartino, Le Quattro Volte, 2010. 
Frequently, Le Quattro Volte takes a step back, revealing the large and expansive nature of the Calabrian land in extreme long shots and deep space. These shots are an opportunity for the viewer to take in the land not as "landscape" (as Nancy describes it - something withdrawn and distant), but as a participatory field alive with presence and agency wherever one might look. Monica Seger cites Gilles Deleuze's remark that the use of deep space "negates the possibility of one clear center or one dominant truth by exposing multiple points of focus." "15 This places the various elements within the frame not only on levels of spatial equality but also ontological equality, as goats and trees (for example) take on similar size and function within the frame (fig. 4). In this way, Le Quattro Volte's lack of "event" (in a traditional narrative sense) becomes a kind of omni-event (or - presence) in which the viewer can find "action" to latch onto in any part of the frame. Monica Seger writes that "such full use of the frame challenges viewers to be a very active audience," 16 as the contemplative space that opens up affords the viewer a kind of freedom of attention that they must take up and use creatively. Frammartino encourages the viewer to "become a cameraman... or an editor"17 and use their attention to create their own cinematic focus and even montage. By using a non-anthropocentric film form, Le Quattro Volte transforms non-event into presence, landscape into land, and viewer into pagan.

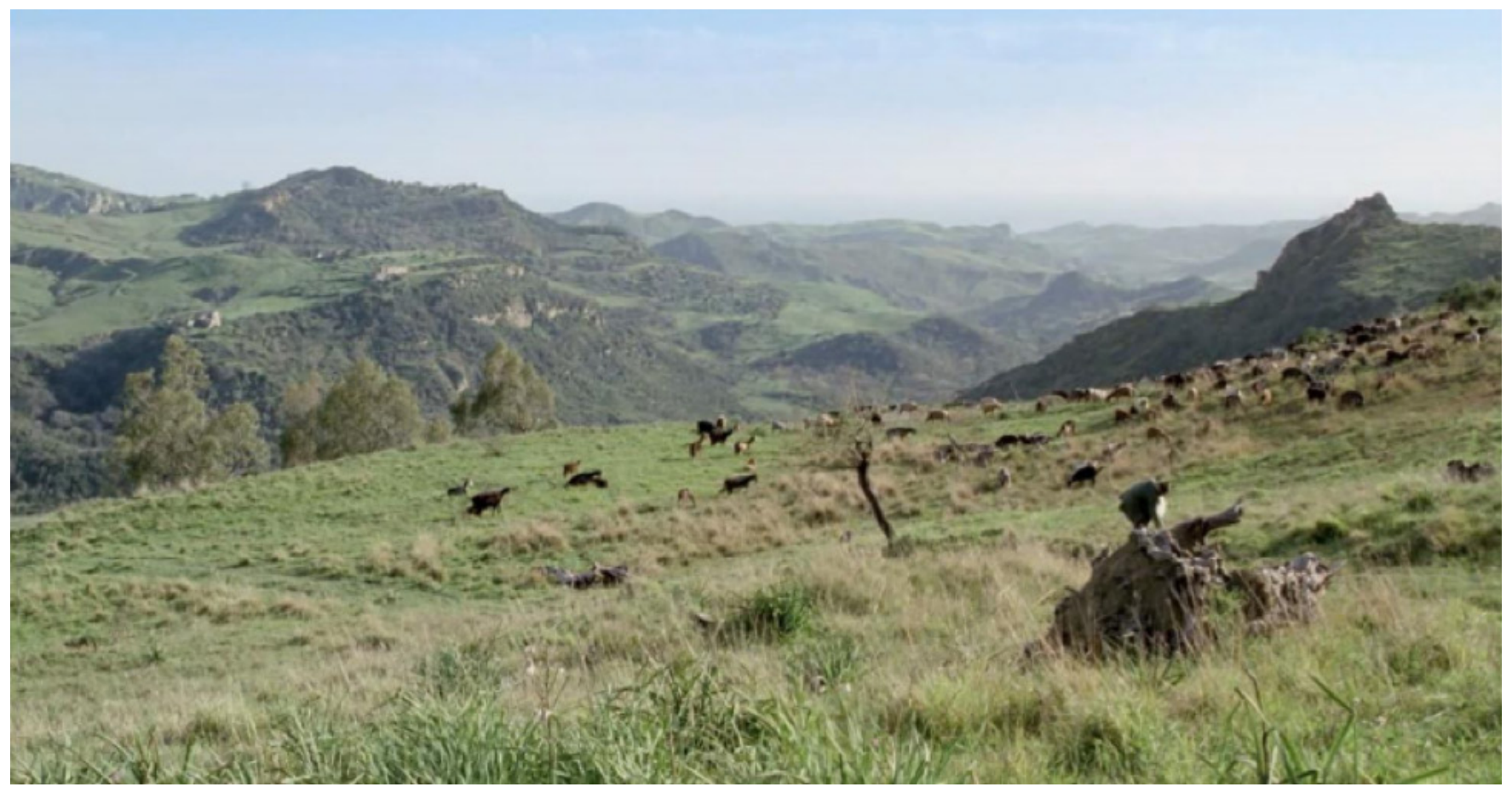

Figure 4. Michelangelo Frammartino, Le Quattro Volte, 2010.

For Nancy, the peasant is not necessarily someone who works in agriculture or lives in the countrythere can be "a peasant in the city, a peasant in thought or in art." 18 Specifically, he writes that the peasant is "anyone who makes his own some corner of the here and now." 19 Le Quattro Volte asks the viewer to do exactly this, and aids them with rhythms and repetitions that bring the viewer into the film's spaces and temporalities. The film does this in part by creating a sense of familiarity for the viewer, returning again and again not only to the same spaces but to the exact same framing of shots. The most frequent shot in the film overlooks a street in the centre of the town, with goats fenced on the left side of the frame, 
an arch in the centre and houses stretching out beyond the right side (fig. 5). We also return repeatedly to an extreme long shot of the town in the hills of Calabria and observe quietly as light and shadows pass over it. The viewer comes to recognize these spaces, perhaps internally saying "Ah, here we are again," and so is drawn into the film world, making it their own for the time being. This familiarity not only brings the viewer to concern himself with the "here and now," as a peasant does, but is also a suggestion to consider the ontological truths of paganism and animism inherent in the film's spaces. The same objects return time and time again as well, forming subtle comic gags which rely on the viewer's ability to recognize the objects. In one extended sequence, a truck is parked on a hill opposite the fenced goats, only to roll down the hill and smash the fence several minutes and shots later, releasing the goats into the town. The objects and beings that populate Le Quattro Volte become inter-related and unified, connected through subtle, delayed action and the viewer's agency.

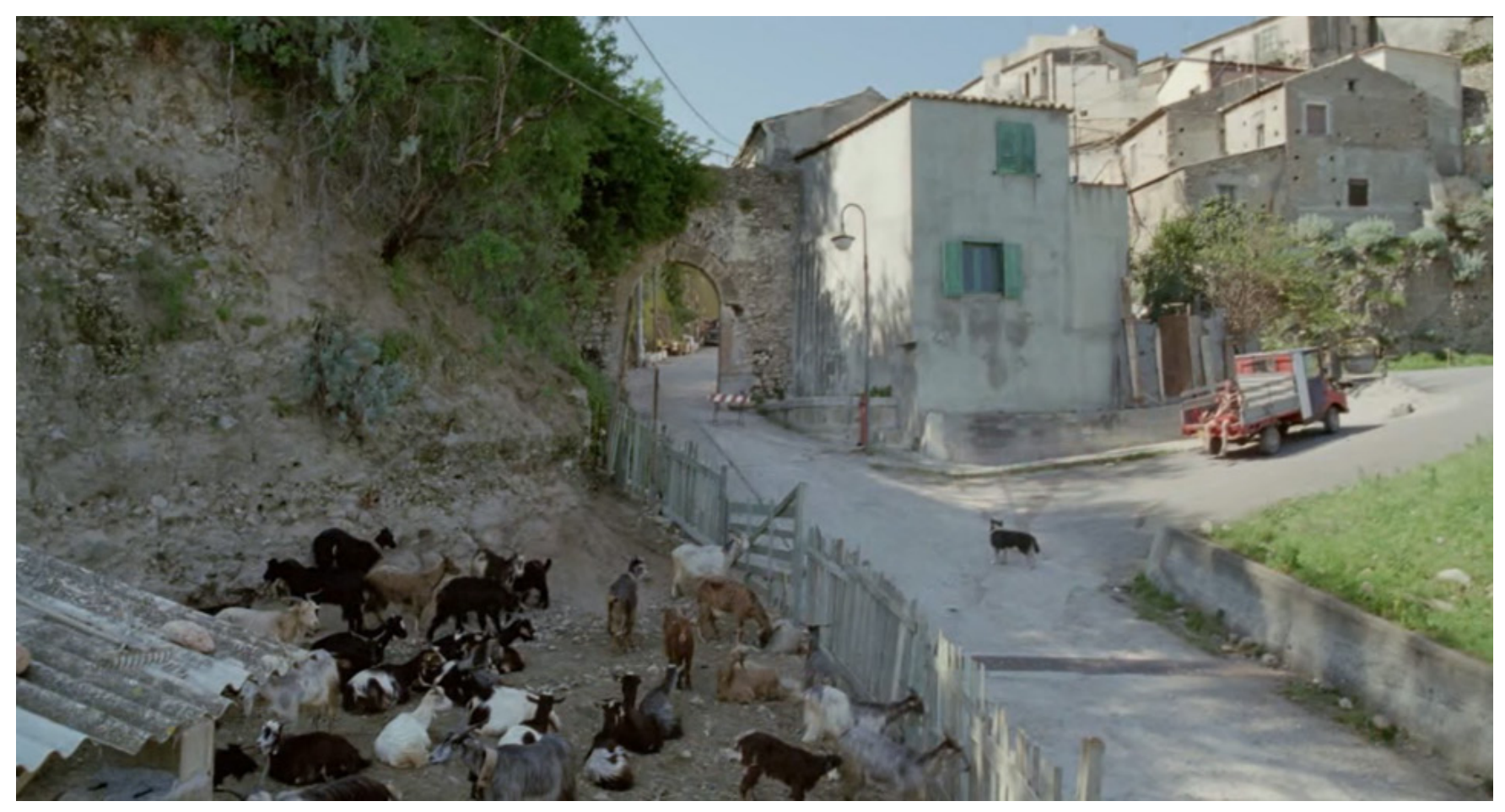

Figure 5. Michelangelo Frammartino, Le Quattro Volte, 2010.

These familiar patterns and returns form several distinct rhythms within the film. As we follow each protagonist in their daily life, we learn of the temporalities and tempos that define their existence. As the film follows the goatherd, for example, the viewer rises with him each day, walks with him on the same path to the countryside, and goes to sleep with him. Frammartino also introduces the viewer to "non-human rhythms"20 in the subsequent sections, as the daily "routines" of animals and objects are explored. These intertwined micro-patterns and micro-rhythms take place within larger seasonal and annual rhythms, marked by the yearly event of the burning of the charcoal (which bookends the film). If a peasant is someone who "works time and place at the same time as the subject of [their] work," 21 Le Quattro Volte needs its viewers to become accustomed to and aware of the spatial and temporal realities of its world in order to make them into peasant and pagan spectators. Accordingly, the viewers are patiently brought into the film's world, into Calabria, so that they can attend to the "subject of their work" - the film. 
The varying temporalities of Le Quattro Volte have an underlying general slowness, seen in the film's lingering on scenes for extended periods of time in long, uninterrupted takes. Slowness in cinema is a relative slowness, as slow cinema films are usually not actually "slow" but rather slower than typical fast-cutting films. "Slow" time in film could also be called "real" time, as it depicts events and places as they unfold at their natural pace. Accordingly, long takes and slowness are a way in which "cyclical, seasonal, and artisanal temporalities seem to impose themselves on the film's pace." 22 Nancy describes the peasant as "one who gives place and time to operations other than his own, to ripenings, to stretches of waiting[...]."23 The spectator of Le Quattro Volte, adjusting to the slowness of rural and country life, is asked to give themselves over to the broader rhythms, temporalities, and meanings of the region.

Slowness in cinema also affords the viewer an active role, complementing the film's use of deep space. In long, slow shots, a contemplative space opens in which the viewer may choose what to focus on and bring in their own affective responses and thoughts. The film does not happen to the viewer, rather the viewer must meet it halfway and complete the cinematic act. In this way, the film becomes the spectator's object of work, and they become a spectatorial peasant in concerning themselves with the object of their work as it lies before them. They enter the spaces of Calabria and Le Quattro Volte and become occupied by and with the land and the film.

Corrieri references Theodor Adorno's idea that slowness relates to "the tempo, patience, and perseverance, of lingering with the particular." 24 I understand particularity as another form or attribute of presence, as it relates to the autonomy and individuality of things. By returning to the same objects and places and allowing them to unfold at their own pace, Le Quattro Volte affirms the particularity of objects and beings. With slow time, the world is disclosed in its "complexity, richness, and mystery," 25 allowing for the viewer to take in the world in its specificity and depth. The objects and beings of Le Quattro Volte are never metaphors or representations, revealing that "in all things, in every respect, each time distinct and singular, there is a presence."26

Le Quattro Volte is a film that gestures beyond itself, outwards beyond the bounds of the frame and image. With a strong sense of off-screen space, the film urges the viewer to consider that presence is not limited to what is immediately visually available, instead extending throughout the region and (perhaps) world. An instance of movement or quasi-action "always overlaps in time and space with another." 27 In the first section of the film, the camera slowly swings back and forth across a long street, visually alternating focus between goats, a crucifixion recreation procession, and a dog. The multitude of co-existing action gives a sense of profound simultaneity; various and endless micro-actions and movements are occurring everywhere. The frame ceases to demarcate the beginning and end of the world, replaced by an openness that gives the impression that "that which has been captured on film goes far beyond what the camera has recorded." 28 Frammartino achieves this effect through editing, camera movement, and (in theory) an active audience who maintains a visual memory of spaces that no longer occupy the frame. He also creates a densely interwoven sonic collage in which the sounds of multiple spaces can be heard simultaneously. The film opens with shots of charcoal burning, accompanied by sounds of men working with the mounds of coal. As the film cuts to the town, the sounds of the work continue to be heard, indicating simultaneity and co-existence. Acousmatic sound (sound in which the source is not visually seen) is also common - in the context of Le Quattro Volte, the effect of acousmatic sound is not one of disjuncture but rather continuity, as the sound offers assurance that a cut or camera movement does not mean the end of any of the film's many quasi-narratives. By creating this kind of radical openness, simultaneity, and continuity, the film enacts the mode of being of the pagan, who "lives in the continuous presence of the gods," and for whom "gods are present in each corner of the field." 29 
This continuity and openness suggested by off-screen space and sound is one of several suggestions by Frammartino that the world of Le Quattro Volte is not self-contained or self-enclosed - that spaces outside of the film, including the spectator's own space, share in the ontological truths of the peasant and the pagan. The cyclicality of the film proposes that its broad narratives and patterns will continue temporally beyond the closing credits. Engaged spectatorship serves this end as well, since the viewer's active role in constructing and completing the film's meaning ascribes a kind of "liveness" to the viewing experience. Because of these effects, Augusto Corrieri writes that the film "does not happen 'there', but rather 'here'," opening onto "'our' animal, vegetable, and mineral lives." 30 The dichotomy between the film world and spectator's world is diminished, as the viewing experience itself is given life and presence.

In between each of the four sections, there is a brief moment of "death," a pause between lives as the soul migrates from one body to another. For a few seconds, the viewer is faced with a black screen. Coupled with the typical darkness of the viewing space, a situation of cinematic darkness arises. Corrieri understands the moment of cinematic darkness as "a suspension inviting us to acknowledge the simple fact of being here," in which "the audience becomes an audience, the cinema becomes a place." 31 There is the potential here for a phenomenal coinciding of the "over there" of the cinematic world with the "in here" of the viewing experience. The act of cinematic spectatorship is revealed in a reflexive movement but is not revealed as something different or alien to the world of the film. Instead, the film creates a contemplative moment in which the rhythms, temporalities, and truths of Calabria can penetrate the flatness of the screen and pervade the viewing space.

Vivian Sobchack's phenomenological conception of the cinematic sublime is helpful for understanding these moments in Le Quattro Volte. For Sobchack, film creates a "vacillation" between "our intentional relocation 'elsewhere' on the screen and our fleshy presence 'here and now' in the theater." 32 Potentially, film can bring about a phenomenal state in which the viewer co-exists in both spaces at once: "Thus, in its most heightened state as at the movies, our sense of transcendence in immanence not only relocates us 'beyond' the presentness of our flesh to dwell in the on-screen world, but also refers us reflexively (and without a thought) back to our fleshy presence." 33 Sobchack contends that these kinds of cinematic experiences bring the viewer into "non-metaphorical contact with the film" and transcend "traditional subject-object, here-there, inside-outside dichotomies." ${ }^{34}$ I believe that for an active and engaged spectator, this experience is realized in Le Quattro Volte. In the moments of darkness that intersect and bookend the film, there is an opportunity to recognize potential for non-anthropocentric, peasant, and pagan relation to the land and its contents. After all, Calabria is not some fantastical fictional location, but a real place that in fact does exist in the "here and now" of the viewer's own world and reality.

Michelangelo Frammartino's Le Quattro Volte is thus best understood as an invitation - an opportunity. Frammartino, using framing, rhythm, off-screen space, and cinematic darkness, creates an opportunity in which the spectator might enact what Jean-Luc Nancy would describe as a "peasant" and "pagan" relationship to the natural world. The film requests a kind of radically active and open spectatorship in which Frammartino's non-anthropocentric project can take on truth and meaning beyond the boundaries of the frame. What emerges here is the striking aliveness and presence of all things - their autonomy, significance, and universal meaning. Le Quattro Volte suggests that the Earth is nothing other than an overwhelming multitude of presence, in which the viewer finds themselves surrounded not by inert and anonymous objects but by an innumerable community of varying modes of autonomous being; what one might call peers. 


\section{Endnotes}

1 Eugenio Renzi, "In Conversation with Michelangelo Frammartino," in Le Quattro Volte: A Film by Michelangelo Frammartino (London: New Wave Films, 2010), 5.

2 From the film's pressbook: "in the backcountry of southern Italy's mountainous region of Calabria, an old shepherd leads his flock to pasture along paths in the hills which have fallen into disuse. Every morning, the church housekeeper trades a handful of the church's dust for some of the shepherd's fresh milk. Every evening, the elderly shepherd dissolves the 'magic' powder in water and drinks this mixture to remedy his aches and pains. One day, he doesn't show up for their trade. The next day, he dies in his bed as his goats keep vigil over his passing. A kid takes its first steps, but he is slower than the rest of the flock and falls behind. He falls into a ditch in the middle of the forest. Unable to climb out, he bleats for help, but neither the new shepherd, nor his dog, hear him. The flock leaves the kid in their wake, leaving him to his fate. When he finally emerges from the ditch, he finds that he is alone. He wanders aimlessly until, as night begins to fall, he stumbles onto a majestic fir tree in which he seeks shelter. The following spring, the village residents come to fell this tree for the annual 'Pita' festivities which have taken place there for centuries. They saw off its branches and carry its stately trunk back to the village where it is erected in the main square. Once the village festivities are over, the trunk of the fir tree is sold to charcoal makers. It is then cut into logs and used to build the hearth and chimney of the charcoal kiln where it will also be burned as fuel. The kiln, which has been covered in straw and clay, is lit, and begins to smoke. Once the fire has gone out, this time-old technique, which has been passed down from generation to generation, will have transformed the living, vegetable matter of the wood into an inert, mineral matter which is brittle and crumbles easily: charcoal." New Wave Films, "Synopsis," in Le Quattro Volte": A Film by Michelangelo Frammartino (London: New Wave Films, 2010), 2.

3 Michelangelo Frammartino, "Director's Statement," in Le Quattro Volte: A film by Michelangelo Frammartino (London: New Wave Films, 2010), 4.

$4 \quad$ Frammartino, "Director's Statement," 4.

$5 \quad$ Monica Seger, "Le Quattro Volte, All at Once." The Italianist 34, no. 2 (2014), 292.

6 Laura McMahon, "Animal Agency in Le Quattro Volte." Screen 56, no. 1 (2015), 108.

7 Augusto Corrieri, “There as Here: Living Ecologies in Le Quattro Volte.” Performance Research 24, no. 6 (2019), 23.

8 Renzi, "In Conversation with Michelangelo Frammartino," 8.

9 Jean-Luc Nancy, "Uncanny Landscape," in The Ground of the Image (New York: Fordham University Press, 2005), 55.

10 Nancy, 56.

11 Nancy, 56.

12 Nancy, 56.

13 Corrieri, "There as Here: Living Ecologies in Le Quattro Volte," 25.

14 Corrieri, 26.

15 Seger, "Le Quattro Volte: All at Once," 292.

16 Seger, 296.

17 Seger, 297.

18 Nancy, "Uncanny Landscape," 56.

19 Nancy, 55.

20 Corrieri, "There as Here: Living Ecologies in Le Quattro Volte," 25.

21 Nancy, "Uncanny Landscape," 56.

22 Tiago de Luca, "Natural Views: Animals, Contingency, and Death in Carlos Reygada’s Japon and Lisan dro Alonso's Los Muertos," in Slow Cinema, ed. Tiago de Luca and Nuno Barrados Jorge (Edinburgh: Edinburgh University Press, 2016), 219.

23 Nancy, "Uncanny Landscape," 56.

24 Corrieri, "There as Here: Living Ecologies in Le Quattro Volte," 26.

25 Tiago de Luca and Nuno Barradas Jorge, "Introduction: From Slow Cinema to Slow Cinemas," in Slow 
Cinema ed. Tiago de Luca and Nuno Barradas Jorge (Edinburgh: Edinburgh University Press, 2016), 16.

26 Nancy, "Uncanny Landscape," 57.

27 Seger, "Le Quattro Volte: All at Once," 292.

28 Frammartino, "Director's Statement," 4.

29 Nancy, "Uncanny Landscape," 56.

30 Corrieri, "There as Here: Living Ecologies in Le Quattro Volte," 27.

31 Corrieri, 28.

32 Vivian Sobchack, "Embodying Transcendence: On the Literal, the Material, and the Cinematic Sublime." Material Religion 4, no.2 (2008), 197.

33 Sobchack, 197.

34 Sobchack, 198.

\section{Bibliography}

Corrieri, Augusto. "There as Here: Living Ecologies in Le Quattro Volte." Performance Research 24, no. 6 (2019): 22-28. https://doi.org/10.1080/ 13528165.2019.1686579.

de Luca, Tiago. "Natural Views: Animals, Contingency, and Death in Carlos Reygadàs Japon and Lisandro Alonso's Los Muertos," in Slow Cinema, 219-230. Edited by Tiago de Luca and Nuno Barradas Jorge. Edinburgh: Edinburgh University Press, 2016.

de Luca, Tiago and Barrados Jorge, Nuno. "Introduction: From Slow Cinema to Slow Cinemas," in Slow Cinema, 1-24, ed. Tiago de Luca and Nuno Barradas Jorge. Edinburgh: Edinburgh University Press, 2016.

Frammartino, Michelangelo. “Director's Statement.” In Le Quattro Volte: A Film by Michelangelo Frammartino, 4. London: New Wave Films, 2010.

Frammartino, Michelangelo, dir. Le Quattro Volte. 2010. Italy: New Wave Films, 2011. DVD.
McMahon, Laura. "Animal Agency in Le Quattro Volte." Screen 56, no. 1 (2015): 108-114. https://doi.org/ 10.1093/screen/hjv006.

Nancy, Jean-Luc. "Uncanny Landscape," in The Ground of the Image, 51-62. New York: Fordham University Press, 2005.

New Wave Films. "Synopsis," in Le Quattro Volte: A Film by Michelangelo Frammartino, 2. London: New Wave Films, 2010.

Renzi, Eugenio. "In Conversation with Michelangelo Frammartino," in Le Quattro Volte: A Film by Michelangelo Frammartino, 5-8. London: New Wave Films, 2010.

Seger, Monica. "Le Quattro Volte: All at Once." The Italianist 34, no. 2 (2014): 292-297. https://doi.org/10.1179/ 0261434014 Z.00000000089.

Sobchack, Vivian. "Embodying Transcendence: On the Literal, the Material, and the Cinematic Sublime." Material Religion 4, no. 2 (2008): 194-203. 